\title{
Population Dynamics and Forecasting of Cotton Pink Boll Worm (Pectinophora Gossypiella, (Saundars) Lepidoptera: Gelechiidae) in Punjab, Pakistan
}

\section{Syed Ismat Hussain ${ }^{1}$, Khalid Mehmood $^{2}$,Mudassar Khaliq ${ }^{3}$, Habib Anwar ${ }^{1}$, Syed Muhammad Zaka ${ }^{4}$,Ateeq ur Rehman ${ }^{5 *}$, Muhammad Shahid ${ }^{6}$, Syed Atif Hasan Naqvi ${ }^{5 *}$, Ummad ud Din Umar ${ }^{5}$ and Muhammad Asif Zulfiqar $^{7}$}

${ }^{1}$ Govt. of Punjab, Department of Agriculture, Pest Warning and Quality Control of Pesticides, Punjab, Pakistan; ${ }^{2}$ University of Agriculture, Faisalabad, Pakistan, Sub campus Burewala, Pakistan; ${ }^{3}$ Aridzone Research Institute, Bhakkar, Pakistan; ${ }^{4}$ Department of Entomology, Bahauddin Zakariya University, Multan, Pakistan; ${ }^{5}$ Department of Plant Pathology, FAS and T, Bahauddin Zakariya University, Multan, Pakistan; ${ }^{~}$ Plant Pathology Research Institute, Ayub Agriculture Research Institute, Faisalabad, Pakistan; ${ }^{7}$ AARC, Research and Training Station, BZU, Multan, Pakistan.

\begin{abstract}
Pink boll worm (Pectinophora gossypiella, S. Lepidoptera: Gelechiidae) is one of the most destructive pests of cotton. Observations were recorded about pest infestation. Metrological data was collected of each district's head quarter on daily basis for the year 2017. For accumulation of degree days model, Huber's method was adopted and data for calculation of generations by accumulating progressive degree days was observed highly significant i.e., $P>0.0001$. In the present study, the accumulation of degree days for its forecasting was calculated from 1st January by using the metrological data and base line temperature and found 7 generations of pink boll worm to be found in all districts. Data for moths trapped in sex pheromone traps was noted as highly significant i.e., $P>0.0001$. Peaks of moth catches in 14 districts were observed in the month of September to October while for pest survey $\mathrm{P}=2 \mathrm{X} 10-16$ were highly significant meaning that all variables had significant result in response to ETL. The results by pest survey of pink boll worms in cotton fields depicted that the spots above economic threshold level (AETL) was varying between $0.4 \%$ in districts viz., D G Khan and Rajanpur to a maximum of 5.0\% in district Vehari. Below economic threshold level (BETL) was varying between $0.4 \%$ in districts D G Khan and Rajanpur to a maximum infestation found in district Vehari at 23.1\%. The population peaks indicate the overlapping seven generations of pink boll worm out of which 5 active generations were in cotton season giving the thresh hold time of start of emergence of $1^{\text {st }}$ generation and its $50 \%$ emergence.

Received | February 11, 2021; Accepted | July 01, 2021; Published | September 07, 2021

*Correspondence | Ateeq ur Rehman and S. Atif H. Naqvi, Department of Plant Pathology, FAS and T, Bahauddin Zakariya University, Multan, Pakistan; Email: ateequrrehman@bzu.edu.pk; atifhasanshah@hotmail.com

Citation | Hussain, S.I., K. Mehmood, M. Khaliq, H. Anwar, S.M. Zaka, A-u. Rehman, M. Shahid, S.A.H. Naqvi, U-u.D. Umar and M.A. Zulfiqar. 2021. Population dynamics and forecasting of cotton pink boll worm (Pectinophora Gossypiella, (Saundars) Lepidoptera: Gelechiidae) in Punjab, Pakistan. Pakistan Journal of Agricultural Research, 34(4): 732-741.

DOI | https://dx.doi.org/10.17582/journal.pjar/2021/34.4.732.741
\end{abstract}

Keywords | Cotton, Pectinophora gossypiella, Degree days, Survey, Pheromone traps, Forecasting, Lepidoptera

\section{Introduction}

$\mathrm{C}$ otton (Gossypium birsutum L.) is the most important crop of Pakistan. It contributed 1\% share in GDP of Pakistan and 5.2\% in the agriculture value addition with and annual production of 10.671 million bales in 2016-17 (Zalucki and Furlong, 2005). Cotton crop is attacked by a hundred of insect pests 
but only a few have potential threat of damaging (Jeremy, 2017). Almost 150 species of insect pests have been reported to attack this crop in sub-continent (Agrawal, 1987). Among the chewing pest's pink boll worm (Pectinophora gossypiella, S. Lepidoptera: Gelechiidae) is one of the most destructive pests of cotton (Sarwar, 2017). Since the introduction of genetically engineered Bt cotton due to its insecticidal proteins some major pests of cotton like American (Helicoverpa armigera) and spotted (Earias vitella (Fab.) and Earias insulana (Boisd) and pink boll worm (Pectinophora gossypiella, S. Lepidoptera: Gelechiidae) were effectively controlled but now the resistance in pests against $\mathrm{Bt}$ has decreased the benefits (Wan et al., 2017). Resistance has been reported in pink boll worm against Bt proteins in China (Wan, 2012). Amongst the integrated pest management approach, pest monitoring is considered to be the best one for the control of this dangerous pest. Process of pest monitoring is based on the tools like pest survey, light and pheromone traps and sticky traps of various colors (Yenumula and Prabhakar, 2012). Pest monitoring can be helpful for a number of objectives like: (a) prediction of coming generations (Zalucki and Furlong, 2005); (b) ecological studies (Pathak, 1968; Crummay and Atkinson, 1997) (c) tracking migration of insects (Hirao et al., 2008); (d) starting date for biofix or phenology models; (Drake et al., 2002); (e) timing of pest arrivals in agro-ecosystems (Knutson and Muegge, 2010); (f) starting field scouting and sampling procedures and $(\mathrm{g})$ timing of pesticide application (Klueken et al., 2009; Lewis, 1981). Researchers have forecasted the peaks of pink bollworm population using pheromone traps in USA by the degree days' accumulation (Lewis, 1981; Merrill et al., 2011; Toscano et al., 1979).

The study of population dynamics of a particular pests it is relating with metrological data for forecasting the population peaks could be very helpful for an effective ICT based IPM tool. This study covers the pest monitoring and forecasting of pink boll worm in Punjab, Pakistan by using the data of field surveys, pheromone traps and metrological data.

\section{Materials and Methods}

\section{Metrological data}

Metrological data was collected of each district's head quarter on daily basis from the website of Pakistan MeteorologicalDepartment(ZaluckiandFurlong,2005).
Accumulation of degree days and development of threshold Annual degree days for the whole years were calculated using Microsoft Excel by determining daily minimum and maximum temperatures $\left({ }^{\circ} \mathrm{C}\right)$, and the base temperature for the insect (pink boll worm). The DD for each day were converted into Accumulated Degree Days (ADD) for year 2017, starting from the $1^{\text {st }}$ January and ending on the $31^{\text {st }}$ December. For accumulation of degree days Huber's method (Zalucki and Furlong, 2005) was adopted: Lower development threshold: $55.0^{\circ} \mathrm{F} \quad\left(12.8^{\circ} \mathrm{C}\right)$ Upper development threshold: $86.0^{\circ} \mathrm{F}\left(30.0^{\circ} \mathrm{C}\right)$ (Table 1$)$.

\section{Table 1: Degree-day accumulations required for each stage of development. \\ Season \\ DD $\left({ }^{\circ} \mathbf{F}\right) \mathrm{DD}\left({ }^{\circ} \mathbf{C}\right)$ \\ Start of spring emergence: \\ $500.0 \quad 277.8$ \\ Peak of spring emergence: \\ $1180.0 \quad 655.6$ \\ End of spring emergence: \\ $2200.0 \quad 1222.2$ \\ Summer generation time (adult to adult) $\quad 800.0 \quad 444.4$}

*Start date: January 1, 2017.

\section{Pheromone traps}

Pheromone traps were installed in each tehsil @ 2 per tehsil and regular observations on moth catches were recorded on daily basis. Pheromone traps were installed throughout the year starting from the $1^{\text {st }}$ January in each tehsil in the cotton field. Traps were comprised of plastic containers $(12 \mathrm{~cm}$ diameter, $20 \mathrm{~cm}$ height), funnels $(3.5 \mathrm{~cm}$ diameter) and pheromone dispensers (inside center of plastic rooftop). A cotton swap soaked with bifenthrin $10 \mathrm{EC}$ was used inside the trap as killing agent of the trapped pink boll worm moths. Pheromone dispensers and cotton swaps were replaced every 15 days. Traps were placed within the top $15 \mathrm{~cm}$ of cotton foliage. Traps were re-baited at lures after one-month intervals and moths captured in each trap were counted daily.

\section{Random pest survey}

Pest scouting teams were consisting of one agriculture officer, one field assistant/pest surveyor with one or two gardeners for pest scouting in each tehsil. Data was collected from 14 districts and their 46 tehsils of cotton zone (core area) of Punjab. Each team conducted pest scouting 5 days per week covering 8-10 spots per day (40-50 spots per week) from April to October. Observations were recorded about pest infestation. In core cotton areas, each Union Council (UC) was covered at least on weekly basis in order to have more accurate picture of pest infestation in 
that particular Tehsil/District. The teams and their survey were counterchecked by district and divisional supervisors. For pest scouting of pink boll worm 100 cotton bolls were collected randomly from a field and dissected with a fine blade to check the infestation of this pest. $5 \%$ infestation was considered as economic thresh hold level (ETL) for pink boll worm.

\section{Statistical analysis}

The data was analyzed using ANOVA technique and multiple comparisons of means through Duncan's multiple new range test (Steel and Torrie, 1984). The means were converted into graphics for easy comparisons between years, population of moths, and degree days.

\section{Results and Discussion}

Calculation of generations of pink boll worm according to degree days model

Data for calculation of generations by accumulating progressive degree days is highly significant i.e. $\mathrm{P}>0.0001$. First generation of pink boll worm started emerging on 5 April and 4 April @ 277.8 DD (degree days) in district Bahawalnagar and Rahimyar Khan, respectively (Figure $1 \mathrm{~A}$ and $1 \mathrm{~B}$ ). The $50 \%$ emergence of PBW @655.6 DD in both districts were on 30 April and 28 April, respectively. The linear graph of generations exhibits almost the same trend of pink boll worm up to $7^{\text {th }}$ generations in both districts (Figure 1A and 1B) because both districts are adjacent and have almost same metrological situation. Generations of pink boll worm forecasted with the help of degree days in the districts D.G Khan and Khanewal exhibit that an early emergence initiated in D.G Khan starting from 27.03.2017 as compared to Khanewal where emergence starts from 10.04.2017 (Figure 1C and 1D). Similarly, the $7^{\text {th }}$ generation@ 3556 DD was also reached early in district D.G Khan on 15.09.2017 as compared to Khanewal i.e. 26.10.2017 (Figure 1C and 1D). The reason for early generations in D.G Khan is due to the existence of this district at the distal end of the south Punjab with a significantly different metrological data. Similarly, an early emergence was observed in Layyah on 24.03.2017 compared with 9.04.2017 in Lodhran. $7^{\text {th }}$ generation reached in Layyah on 03.10.2017 and in Lodhran on 17.10.2017 (Figure 1E and 1F) with a difference of 14 days (earlier in Layyah as Layyah is also a district of D.G Khan Division). Almost same emergence of pink boll worm moth in districts
Multan and Muzaffargarh was forecasted at almost same time (Figure $1 \mathrm{G}$ and $1 \mathrm{H}$ ). But $7^{\text {th }}$ generation in district Muzaffargarh reached 15 days earlier on 9.10.2017 as compared with Multan where $7^{\text {th }}$ generation was reached on 24.10.2017 (Figure 1G and $1 \mathrm{H})$. As the two districts are adjacent and are present on the two brinks of river Chenab so the metrological data is not different for most of the generations calculated by progressive degree days. Generations according to progressive degree days for districts Okara and Pakpattan are illustrate significant difference in the start of emergence of pink boll worm moths between the two districts i.e. 7.04.2017 in Okara and 16.05.2017 in Pakpattan (Figure 2A and 2B). Similarly, all generations in the district Pakpattan are delayed from that of in Okara (Figure $2 \mathrm{~A}$ and $2 \mathrm{~B}$ ) due to the difference in metrological data. Generations of PBW according to progressive degree days in Rahimyar Khan and Rajanpur showed that from emergence to $7^{\text {th }}$ generations all set of dates in Rahimyar Khan are much earlier than that of in Rajanpur with a maximum difference of up to 22 days (Figure 2C and 2D).

Rahimyar Khan is another distal end of south Punjab province having its boundaries with another province Sindh and a desert on its south which is causing early generations of pink boll worm. It is evident that the generations according to degree days in Sahiwal and Vehari are almost same at the start of the emergence but there is a difference of 14 days while reaching at the $7^{\text {th }}$ gen eration i.e. 3.10.2017 in Sahiwal and 17.102017 in Vehari (Figure 2E and 2F).

Population monitoring of pink boll worm with sex pheromone traps

Data for moths trapped in sex pheromone traps is highly significant i.e. $\mathrm{P}>0.0001$. Moth catch data in Bahawalnagar and Bahawalpur (Figure $3 \mathrm{~A}$ and $3 \mathrm{~B}$ ) are on lower ebb between $2^{\text {nd }}$ and $3^{\text {rd }}$ generations and start increasing after that showing peak at the $7^{\text {th }}$ generation. Moth capture data of district D.G Khan and Khanewal shows population peak in district D.G Khan at $50 \%$ emergence whereas in district Khanewal the moth catches reached at maximum at $7^{\text {th }}$ generation (Figure 3C and 3D). The moth catch data of the two districts Layyah and Lodhran is different significantly as Layyah showing population peak at the start of emergence whereas moth population gradually increased from $4^{\text {th }}$ generation to a maximum at $7^{\text {th }}$ generation in Lodhran (Figure $3 \mathrm{E}$ and $3 \mathrm{~F}$ ). 


$\begin{array}{lll}-. \text { Start-Emerg 277.8-DD } & -2 \text { nd-1.G-1471DD } & * \text { 5th-1.G-2722 DD } \\ -.50 \%-E m e r g 655.6-D D & -3 \text { rd-1.G-1888 DD } & -6 \text { th-1.G-3139DD } \\ -1 \text { st-1.G-1054 DD } & -4 \text { th-1.G-2305 DD } & -7 \text { th-1.G-3556 DD }\end{array}$
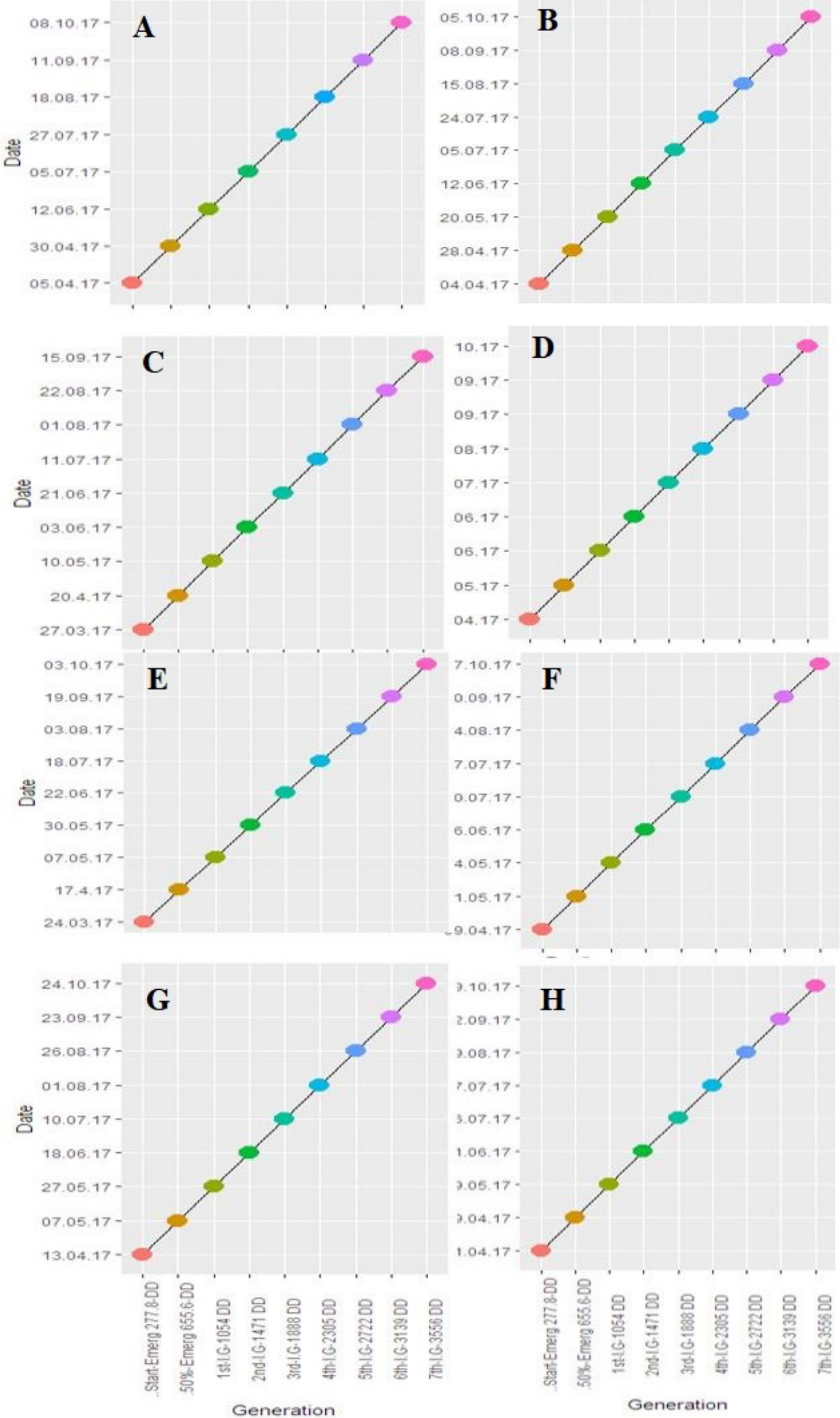

Figure 1: Pink boll worm generations forecasted on the basis of progressive degree days in different districts (A: Baharwalnagar, B: Bahawalpur, C:DG Khan, D: Khanewal, E: Layyah, F: Lodhran, G: Multan, H: Muzaffargarh). 
- ..Start-Emerg 277.8-DD

- .50\%-Emerg 655.6-DD

- 1st-I.G-1054 DD
- 2nd-I.G-1471 DD

- 3rd-1.G-1888 DD

-4th-I.G-2305 DD
- 5th-1.G-2722 DD

- 6th-I.G-3139 DD

- 7th-1.G-3556 DD
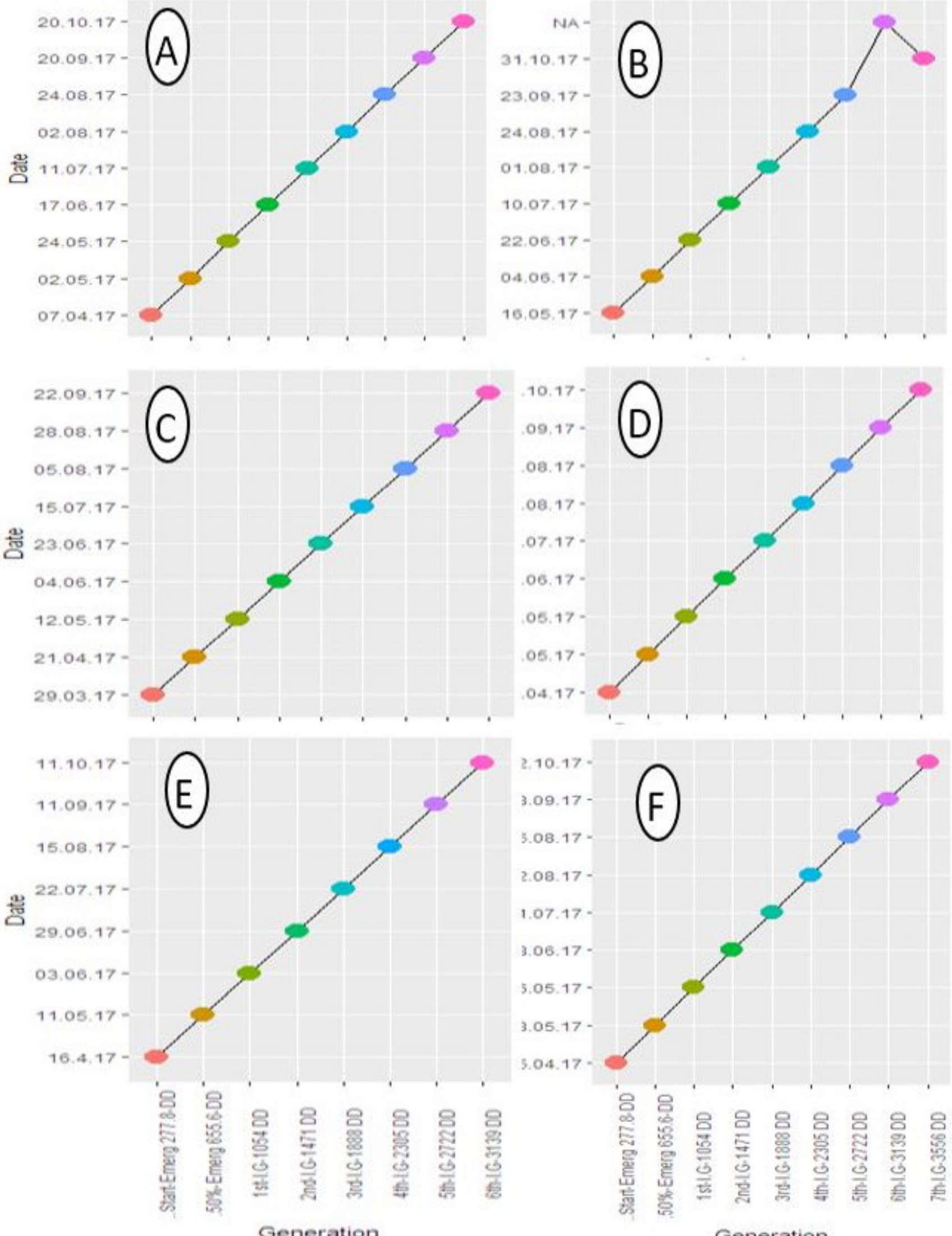

Figure 2: Pink boll worm generations forecasted on the basis of progressive degree days in different districts (A: Okara, B: Pakpattan, $C$ Rabimyar Khan, D: Rajanpur, E: Sabiwal, F: Vehari). 

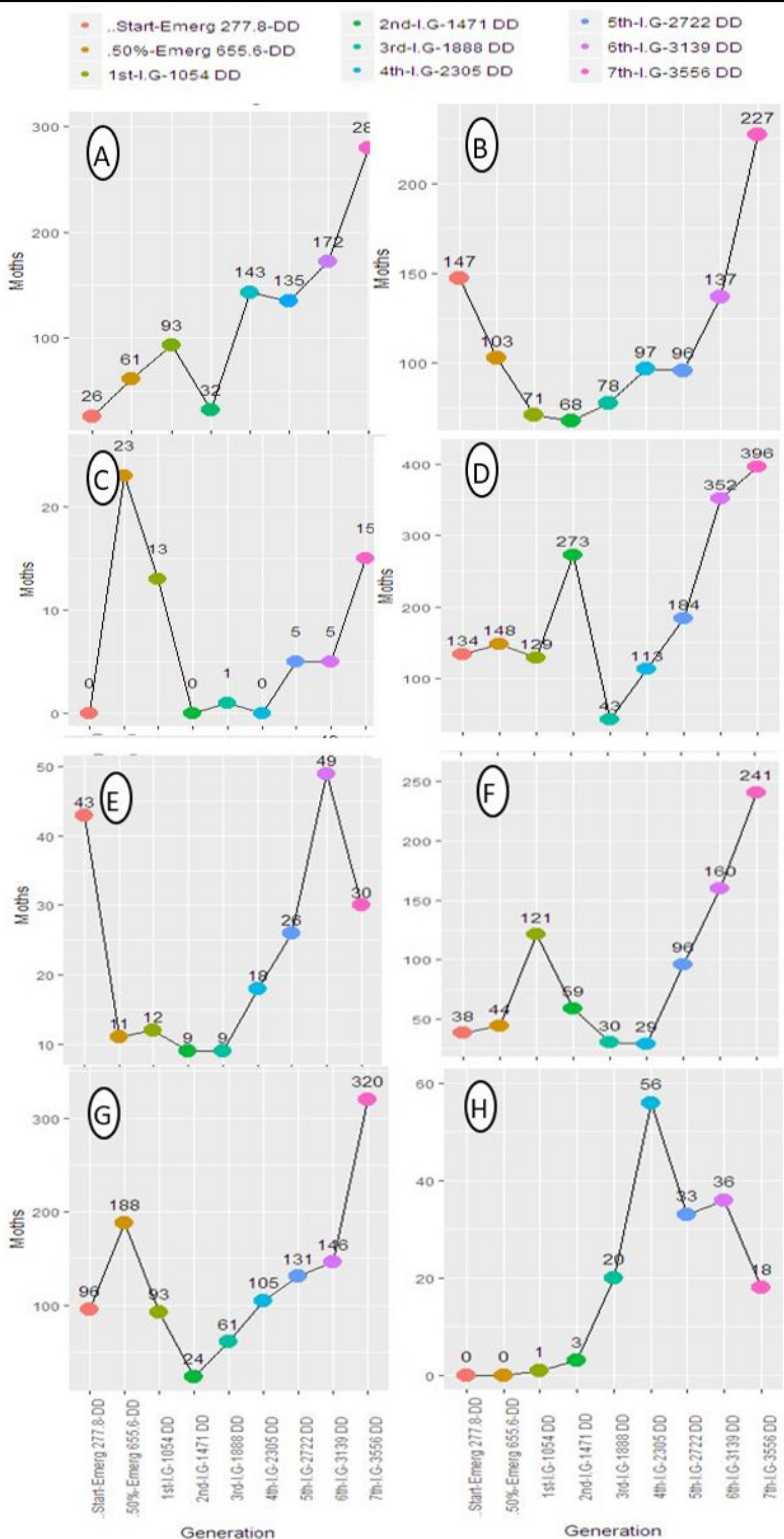

Figure 3: Pink boll worm moth catches in pheromone traps between the generations in different districts (A: Bahawalnagar, B: Bahawalpur, C:DG Khan, D: Khanewal, E: Layyah, F: Lodhran, G: Multan, H: Muzaffargarh). 
- ..Start-Emerg 277.8-DD

- .50\%-Emerg 655.6-DD

- 1st-1.G-1054 DD
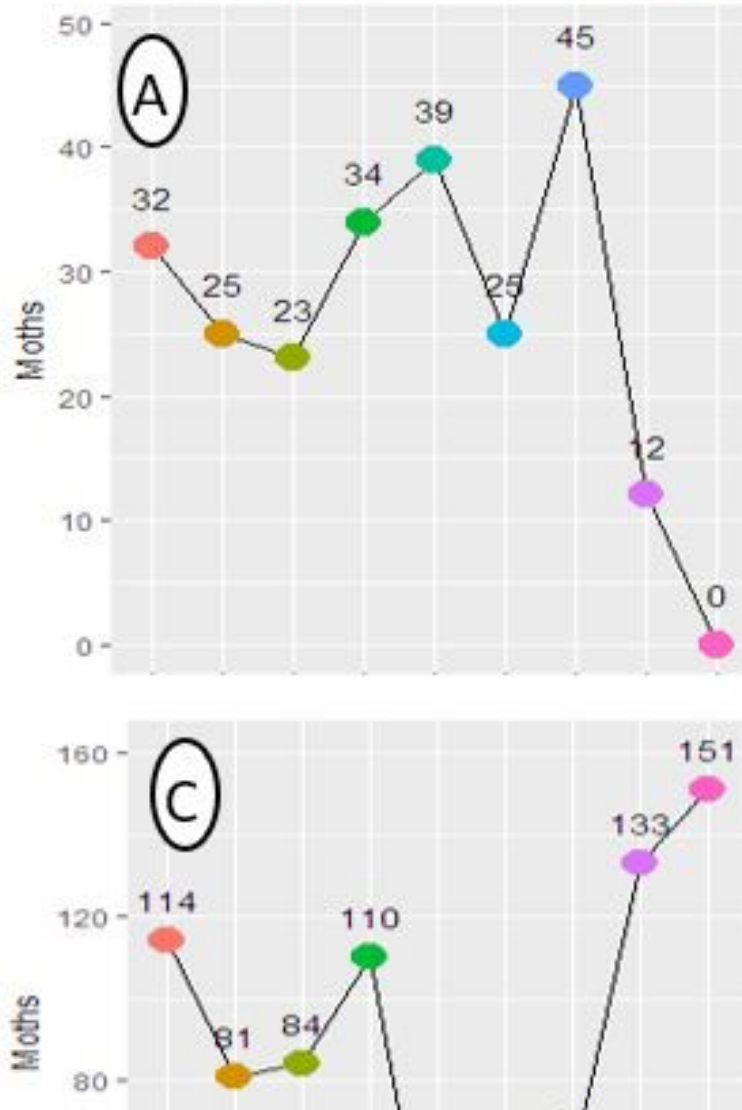

$40-$

40
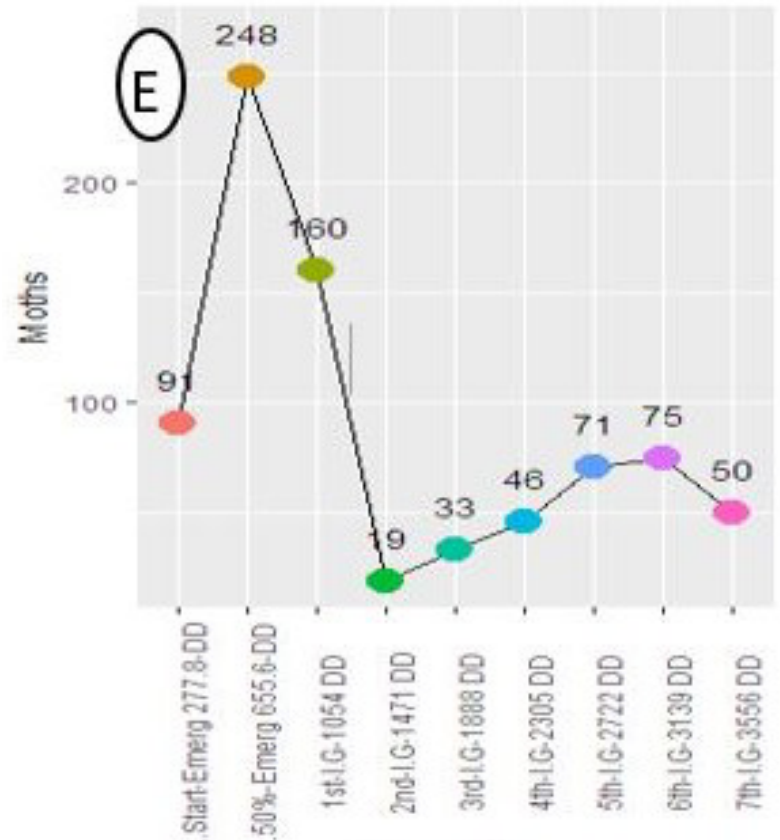

Generation

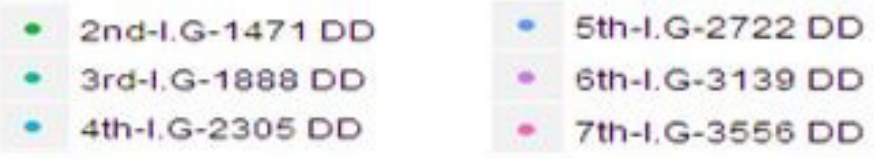

- 7 th-I.G-3556 DD
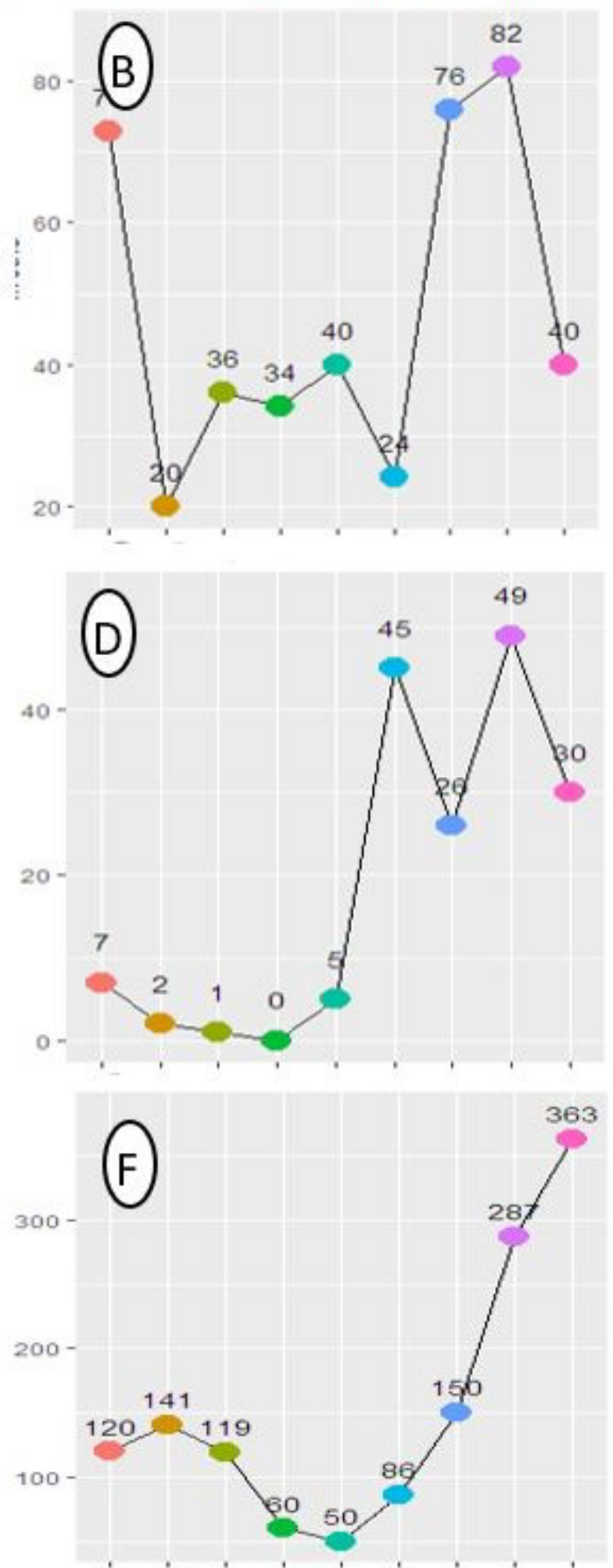

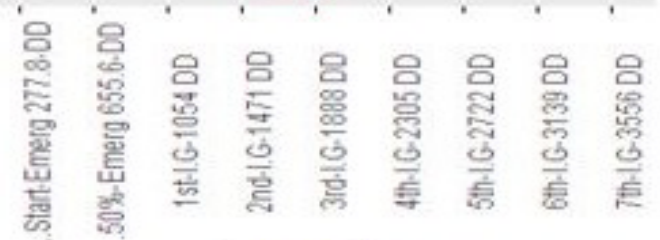

Generation

Figure 4: Pink boll worm moth catches in pheromone traps between the generations in different districts (A: Okara, B: Pakpattan, CRahimyar Khan, D: Rajanpur, E: Sabiwal, F: Vehari). 
In Layyah moth catches started increasing after $3^{\text {rd }}$ generation and reached at maximum at $6^{\text {th }}$ generation whereas in Lodhran moth catches started increasing after $4^{\text {th }}$ generation and got a peak at $7^{\text {th }}$ generation (Figure 3F and 3F). Regarding pink boll worm moth catches in pheromone trap the peak population was recorded in Multan was at $7^{\text {th }}$ generation and in Muzaffargarh at $4^{\text {th }}$ generation (Figure $3 \mathrm{G}$ and $3 \mathrm{H}$ ). Moths trapped in pheromone traps in Okara decline after $5^{\text {th }}$ generation as compared with Pakpattan where moth catches gradually increase after $4^{\text {th }}$ generation to a maximum at 6 th generation (Figure $4 \mathrm{~A}$ and $4 \mathrm{~B}$ ). Male tarps in sex pheromone traps were recorded maximum at $5^{\text {th }}$ generation in Okara and at $6^{\text {th }}$ generation in Pakpattan (Figure $4 \mathrm{~A}$ and $4 \mathrm{~B}$ ). Maximum moth population trapped in pheromone traps in Rahimyar Khan was recorded at $7^{\text {th }}$ generation and in Rajanpur at $6^{\text {th }}$ generation (Figure $4 \mathrm{C}$ and 4D). Whereas in Sahiwal and Vehari, both districts showing peak of moth captured in pheromone traps at $6^{\text {th }}$ generation (Figure $4 \mathrm{E}$ and $4 \mathrm{~F}$ ).

Population monitoring of pink boll worm by pest survey of cotton crop in the field

District $\mathrm{P}$-value $=2 \times 10^{-16}$ are highly significant meaning thereby that all variables have significant result in response to ETL. The results by pest survey of pink boll worms in cotton fields depict that the spots above economic threshold level (AETL) is varying between $0.4 \%$ in districts DG Khan and Rajanpur to a maximum of $5.0 \%$ in district Vehari.

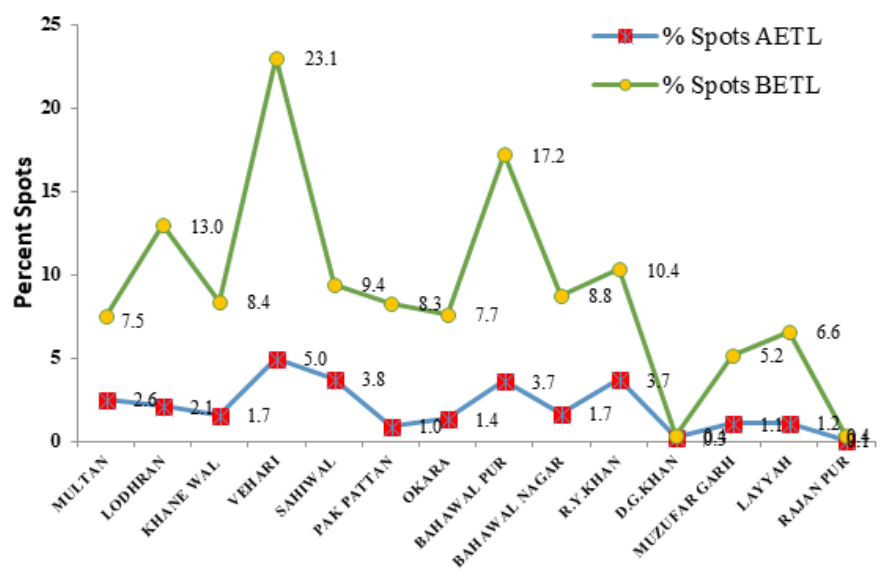

Figure 5: District wise infestation of Pink boll worm.

Similarly, below economic threshold level (BETL) is varying between $0.4 \%$ in districts DG Khan and Rajanpur to a maximum infestation found in district Vehari at $23.1 \%$ followed by Bahawalpur at $17.2 \%$. The vertical lines crossing through moth population specify consecutive generations of pink boll worm. And the same is endorsed by the pest survey and generations deduced using metrological data by accumulating the degree days (Figure 5).

Population forecasting models are there for many organisms (Gabriella and Douglas, 1998). Hamed and Nadeem (2010) reported that for spotted boll worm the DD model predicted that the first, second and third generations of $E$. vitella produced each year would occur at the accumulation of 2755, 3210 and 3665 Celsius DD, respectively. Borchert et al. (2003) reported forecasting of a particular pest can be different on the basis of different geographical reasons. Beasley and Adams (1996) accumulated degree days from the $1^{\text {st }}$ February for prediction of pink boll worm and from the $1^{\text {st }}$ March for prediction of blueberry maggot flies (Teixeira and Polavarapu, 2001). Accumulated DD for spotted boll worm from $1^{\text {st }}$ January by using the base developmental temperature. In the present study the accumulation of degree days for its forecasting was calculated from $1^{\text {st }}$ January by using the metrological data and base line temperature and found 7 generations. Five generations of pink boll worm were in the peak cotton season (Teixeira and Polavarapu, 2001). The difference in the number of moth catches in the districts is mainly due to varying number of tehsils in each district. Off season management of pink boll worm includes turning of heaps of cotton sticks, disposal of cotton ginning waste from cotton ginning factories, oil mills and brick kilns etc., which also can affect the emergence of moths from their hibernating habitats. Most of the moth catches peaks in 14 districts were observed in the month of September to October. Our results closely relate with Borchert et al. (2003) who reported that during 1998 the first peak in the moth population of spotted boll worm occurred in the $2^{\text {nd }}$ week of August, the second peak in the 1st week of September and the third peak in the last week of September. Population trends during 1999 increased abruptly in July and first peak occurred in the $1^{\text {st }}$ week of August, second peak was observed in the $1^{\text {st }}$ week of September and the third peak was recorded in the last week of September. Our results closely resemble with that of reference (Manjunatha et al., 2009) who studied the incidence of PBW on different $\mathrm{Bt}$ and Non Bt hybrids and reported that all the Bt cotton hybrids registered significantly lower per cent of rosette flowers (0.01-1.57\%) due to PBW throughout the season. Later it was gradually increased and 
reached to peak level at 140 DAS with damage ranging from 8.72 to 11.57 per cent. Our data results are in contradiction with that of Vadodara and Kheda districts, the infestation of PBW was found up to 94 percent and 27 percent irrespective of the $\mathrm{Bt}$ cotton varieties (Sharma et al., 1985). Our results match closely with reference (Nietschke et al., 2007) who reviewed the average $\mathrm{DD}$ requirements for an insect generation in the order lepidoptera are 559.1, similar to the findings of the present study. The population peaks indicate the overlapping 7 generations of pink boll worm in a cotton season also giving the thresh hold time of start of emergence of $1^{\text {st }}$ generation and its $50 \%$ emergence. Contrary to these results Sharma et al. (1985) documented eleven generations of spotted boll worm under laboratory conditions while Sharma et al. (1985) found many overlapping generations of spotted boll worm during a year under field conditions.

\section{Conclusions and Recommendations}

The overall studies concluded that the moth capture accumulated at range of degree days, pest survey and generations predicted on the basis of degree days model used in this study, almost precisely predict the pink boll worm attack on the cotton crop in Punjab. On the basis of forecasting by this method PBW red alerts can be issued to the farmer community so that they can start integrated pest management measures to control this pest.

\section{Acknowledgements}

Gratitude to Government of the Punjab, Agriculture Department of Pest Warning and Quality Control of Pesticides, Punjab for technical assistance, logistics, POLs, data collection, compilation, and analysis.

\section{Novelty Statement}

The moth capture accumulated at range of degree days, pest survey and generations predicted on the basis of degree days model used in this study, almost precisely predict the pink boll worm attack on the cotton crop in Punjab. On the basis of forecasting by this method PBW red alerts can be issued to the farmer community so that they can start integrated pest management measures to control this pest.
Author's Contribution

Syed Ismat Hussain: Conceived the idea and introduction

Khalid Mehmood: Wrote abstract and introduction Mudassar Khaliq: Wrote methodology and discussion

Habib Anwar, Syed Muhammad Zaka and Ateeq ur

Rehman: Wrote methodology

Muhammad Shahid, Syed Atif Hasan Naqvi and Ummad ud Din Umar: Did SPSS analysis and discussion

Muhammad Asif Zulfiqar: Result and discussion

\section{Conflict of interest}

The authors have declared no conflict of interest.

\section{References}

Agrawal, R.A., 1978. Cotton insect pests and their control, Richer Harvest, 1: 22-29.

Annual Report of Department of Entomology. 2014. BACA, AAU, Anand. pp. 8-9.

Beasley, C.A. and C.J. Adams. 1996. Field based degree day model for pink bollworm (Lepidoptera: Gelechiidae) development. J. Econ. Entomol., 89: 881-890. https://doi. org/10.1093/jee/89.4.881

Borchert, D.M., A. Magarey and G.A. Fowler. 2003. Pest assessment: Old world bollworm, Helicoverpa armigera (Hubner), (Lepidoptera: Noctuidae), USDA-APHIS-PPQ-CPHSTPERAL/NCSU. pp. 9.

Crummay, F.A. and B.W. Atkinson. 1997. Atmospheric influences on light-trap catches of the brown planthopper rice pest. Agric. For. Meteorol., 88: 181-197. https://doi. org/10.1016/S0168-1923(97)00040-3

Drake, V.A., H.K. Wang and I.T. Harman. 2002. Insect monitoring radar: Remote and network operation. Comput. Electron. Agric., 35: 77-94. https://doi.org/10.1016/S01681699(02)00024-8

Gabriella, Z.B. and G.P. Douglas. 1998. Understanding degree-days and using them in pest management decision making, Project ENT 4987, arthropod management in fruit crops, Department of Entomology, Virginia Tech, Blacksburg, VA, pp. 24061-0319.

Hamed, M. and S. Nadeem. 2010. Forecasting of spotted bollworm (Earias vitella (Fab.) 
(Lepidoptera: Noctuidae) Occurrence in Cotton. Pak. J. Zool., 42: 575-580.

Hirao, T.M., M. Murakami and A. Kashizaki. 2008. Effects of mobility on daily attraction to light traps: comparison between lepidopteran and coleopteran communities. Insect Conserv. Diver., 1: 32-39. https://doi.org/10.1111/ j.1752-4598.2007.00004.x

Jeremy, K., 2017. Cotton insect management, research/extension entomologis. Greene South Carolina Pest Management Handbook for Field Crops, Vol. 1.

Klueken, B., B. Hau, Ulber and H.M. Poehling. 2009. Forecasting migration of cereal aphids (Hemiptera: Aphididae) in autumn and spring. J. Appl. Entomol., 133: 328-344. https://doi. org/10.1111/j.1439-0418.2009.01387.x

Knutson, A.E. and M.A. Muegge. 2010. A degree-day model initiated by pheromone trap captures for managing pecan nut case bearer (Lepidoptera: Pyralidae) in pecans. J. Econ. Entomol., 103: 735-743. https://doi. org/10.1603/EC09319

Lewis, T., 1981. Pest monitoring to aid insecticide use. Philos. Trans. R. Soc. Biol. Sci., 295: 153162. https://doi.org/10.1098/rstb.1981.0129

Manjunatha, R., S. Pradeep, S. Sridhar, M. Manjunatha, M.I. Naik, B.K. Shivanna and H. Venkatesh. 2009. Comparative performance of $\mathrm{Bt}$ and non-Bt cotton against bollworm complex. Karnataka J. Agric. Sci., 22: 646-647.

Merrill, R.M., Z. Gompert, L.M. Dembeck, M.R. Kronforst, W.O. McMillan and C.D. Jiggins. 2011. Mate preference across the speciation continuum in a clade of mimetic butterflies. Evolution, 65: 1489-1500. https://doi. org/10.1111/j.1558-5646.2010.01216.x

Nietschke,B.S.,R.D.Magarey,D.M.Borchert,D.D. Calvin and E. Jones. 2007. A developmental database to support insect phenology models. Crop Prot., 10: 1016. https://doi.org/10.1016/j. cropro.2006.12.006

Pakistan Economic Survey, 2016-17. 2017. Ministry of Finance. Government of Pakistan Chapter 2.pp. 19.

Pakistan Meteorological Department. 2018. http:// rmcpunjab.pmd.gov.pk/. Accessed on February $15,2018$.

Pathak, M.D., 1968. Ecology of common insect pests of rice. Ann. Rev. Entomol., 13: 257-294. https://doi.org/10.1146/annurev. en.13.010168.001353

Pink Bollworm: Integrated Pest Management for Cotton in the Western United States. 2016. University of California Statewide IPM Project. University of Arizona Statewide IPM Project. New Mexico State University. U.C. Div. Agric. Sci. Publ., \#3305.

Sarwar, M., 2017. Pink Bollworm Pectinophora gossypiella (Saunders) [Lepidoptera: Gelechiidae] Practices of Its Integrated Management in Cotton. Int. J. Plant Sci. Ecol., 3: 1.

Sharma, I.N., B.S. Lall, R.P., Sinha and B.N. Singh. 1985. Biology of spotted bollworm, Earias vitella (Fab). Bull. Entomol., 26: 38-41.

Steel, R.G.D. and J.H. Torrie. 1984. Principles and procedures of statistics. McGraw Hill Book Co. Inc., pp. 172-177.

Teixeira, L.A.F. and S. Polavarapu. 2001. Postdiapause development and prediction of emergence of female blueberry maggot (Diptera: Tephritidae). Environ. Entomol., 30: 925-931. https://doi.org/10.1603/0046-225X-30.5.925

Toscano, N.C., R.A.V. Steenwyk, V. Sevacherian and H.T. Reynolds. 1979. Predicting population cycles of the pink bollworms on some varieties of cotton in Haryana. Indian J. Entomol., 46: 340-345.

Wan, P., 2012. Increased frequency of pink bollworm resistance to Bt toxin Cry1Ac in China. PLoS One, 7: e29975. https://doi.org/10.1371/ journal.pone.0029975

Wan, P., D. Xu, Y. Cong, Y. Jiang, J. Huang, H. Wang, L. Wu, K. Wang, Y. Wu, A. Carrière, X. Mathias, Li and E.T. Bruce. 2017. Hybridizing transgenic $\mathrm{Bt}$ cotton with non-Bt cotton counters resistance in pink bollworm. Proc. Natl. Acad. Sci., 114(21): 5413-5418. https:// doi.org/10.1073/pnas.1700396114

Yenumula, G.P. and M. Prabhakar. 2012. Division of crop sciences, central research institute for dryland agriculure, Hyderabad, India Pest Monitoring and Forecasting. Integrated Pest Management, Chapter: Pest Monitoring and forecasting, pp. 41-57. https://doi. org/10.1079/9781845938086.0041

Zalucki, M.P. and M.J. Furlong. 2005. Forecasting Helicoverpa populations in Australia: A comparison of regression-based models and a bioclimatic based modeling approach. Insect Sci., 12: 45-46. https://doi.org/10.1111/j.16729609.2005.00007.x 